\title{
Phylogenetic analysis of Calymmatobacterium granulomatis based on 16S rRNA gene sequences
}

\author{
A. B. M. KHARSANY, A. A. HOOSEN, P. KIEPIELA, R. KIRBY* and A. W. STURM \\ MRC Genital Ulcer Disease Research Unit, Department of Medical Microbiology, Faculty of Medicine, \\ University of Natal, Kwa Zulu Natal and *Department of Biochemistry and Microbiology, Rhodes University, \\ Grahamstown, South Africa
}

\begin{abstract}
Calymmatobacterium granulomatis is the aetiological agent of granuloma inguinale - a chronic granulomatous genital infection - and is morphologically similar to members of the genus Klebsiella. This study determined the 16S rRNA gene sequence of $C$. granulomatis and the taxonomic position of the organism in relation to the genus Klebsiella. Genomic DNA was extracted from $C$. granulomatis-infected monocytes and from frozen and formalin-fixed paraffin wax-embedded tissue biopsy specimens from patients with histologically proven granuloma inguinale. The 16S rDNA was amplified by PCR with broad range oligonucleotide primers. The amplified DNA fragments were cloned into $p$ MOS vector, digested with Bam HI and Pst1 restriction endonucleases, hybridised with a gram-negative bacterial probe (DL04), sequenced in both directions by the automated ALF ${ }^{\text {TM }}$ DNA sequencer, verified on an ABI Prism 377 automated sequencer and analysed with DNASIS and MEGA software packages. Sequence analysis revealed DNA homology of $99 \%$ in $C$. granulomatis from the different sources, supporting the belief that the bacteria in the culture and the biopsy specimens belonged to the same species, although there was some diversity within the species. Phylogenetically, the strains were closely related to the genera Klebsiella and Enterobacter with similarities of $95 \%$ and $94 \%$ respectively. $C$. granulomatis is a unique species, distinct from other related organisms belonging to the $\gamma$ subclass of Proteobacteria.
\end{abstract}

\section{Introduction}

Calymmatobacterium granulomatis is a fastidious gram-negative capsulate bacillus found intracytoplasmically within macrophages. It is the aetiological agent of granuloma inguinale, a sexually transmitted disease. The diagnosis of granuloma inguinale is based on the visualisation of 'Donovan bodies' in tissue smears [1]. C. granulomatis cannot be cultured on conventional cell-free media, although occasionally successful growth in embryonated eggs [2,3], and more recently in a monocyte co-culture system, has been achieved [4]. On the basis of ultrastructural morphology and serological characteristics, the organism is considered to be related to members of the genus Klebsiella [5-8].

Analysis of 16S rRNA gene sequences is a useful method for the determination of phylogenetic relation-

Received 6 Oct. 1998; revised version accepted 10 Dec. 1998.

Corresponding author: $\operatorname{Dr}$ A. B. M. Kharsany (e-mail: Kharsany@med.und.ac.za) ships between bacteria and provides a logical basis for taxonomic classification [9-13]. The use of PCR with 16S rRNA primer sequences allows the amplification of bacterial DNA directly from infected host tissue and this DNA can be used for sequence analysis [13-15]. The aims of this study were to determine the $16 \mathrm{~S}$ rRNA sequence of $C$. granulomatis obtained from monocyte co-culture and infected tissue and to establish the taxonomic position of $C$. granulomatis in relation to the genus Klebsiella.

\section{Materials and methods}

\section{Clinical specimens}

Tissue biopsy specimens from three patients with histologically proven granuloma inguinale were used. One biopsy specimen was co-cultured in monocytes as described previously [4], the second was kept at $-70^{\circ} \mathrm{C}$ until analysis, whilst the third specimen was formalinfixed and embedded in paraffin wax. A breast tumour biopsy specimen, uninfected monocytes, pyrogen-free water and laboratory strains of Klebsiella pneumoniae, $K$. oxytoca, Serratia marcescens, Escherichia coli, 
Acinetobacter anitratus and Staphylococcus aureus were used as controls.

\section{Extraction of DNA}

Frozen tissue and monocyte co-culture. The methods used were modified from those described previously [16]. Fragments of the frozen tissue $(c .3 \times 5 \mathrm{~mm})$ were rinsed in sterile water, homogenised and placed in $400 \mu \mathrm{l}$ of digestion buffer $(500 \mathrm{mM}$ Tris, $\mathrm{pH} 9.0$, $20 \mathrm{mM}$ EDTA, $10 \mathrm{mM} \mathrm{NaCl}$ and SDS 1\%) with proteinase $\mathrm{K}$ (Boehringer Mannheim, Germany) at a final concentration of $1 \mathrm{mg} / \mathrm{ml} ; 500 \mu \mathrm{l}$ of the monocyte co-culture suspension were treated similarly. The samples were incubated at $56^{\circ} \mathrm{C}$ for $18 \mathrm{~h}$ with agitation. The proteinase $\mathrm{K}$ was then heat inactivated at $95^{\circ} \mathrm{C}$ for $10 \mathrm{~min}$ and ribonuclease $\mathrm{A}$ (Boehringer Mannheim) was added to a final concentration of $4 \mu \mathrm{g} / \mathrm{ml}$. The samples were incubated at room temperature for $30 \mathrm{~min}$ and then extracted three times with equal volumes of Tris-buffered phenol:chloroform:isoamylalcohol (25:24:1). The DNA was precipitated with absolute ethanol, washed with ethanol $70 \%$, air dried and resuspended in $50 \mu \mathrm{l}$ of water.

Formalin-fixed paraffin wax-embedded tissue. The method used was that described by Wright and Manos [17]. Sections $(10 \mu \mathrm{m})$ from the paraffin wax-embedded tissue were treated with octane and ethanol and then placed in $400 \mu \mathrm{l}$ of digestion buffer with proteinase K. DNA was extracted and precipitated after digestion and heat inactivation was carried out as for frozen biopsy specimens.

\section{$D N A$ amplification and detection}

$P C R$ primers. Broad range oligonucleotide primers directed to positions $8-1390$ of the $E$. coli $16 \mathrm{~S}$ rRNA gene [18] were synthesised by the solid phase phosphoramidite method with a Gene Assembler DNA synthesiser (Pharmacia LKB Biotechnology, USA). Forward primer 8F (5'-AGTTTGATCCTGGCTCAG$\left.3^{\prime}\right)$ and reverse primer 13R (5'-AGGCCCGGGAACGTATTCAC- $3^{\prime}$ ) resulted in the amplification of a fragment of $1382 \mathrm{bp}$.

PCR amplification. PCR amplification of DNA from frozen tissue, paraffin wax-embedded tissue and monocyte co-culture was performed in a volume of $100 \mu \mathrm{l}$ containing $10 \mu \mathrm{l}$ of $10 \times$ PCR buffer $(100 \mathrm{mM}$ Tris-HCI, pH 8.5, $20 \mathrm{mM} \mathrm{MgCl} 2,500 \mathrm{mM} \mathrm{KCl}), 10 \mathrm{mM}$ of each dNTP; $1.0 \mathrm{U}$ of Taq polymerase (Boehringer Mannheim); 20 pmoles of each primer and $5 \mu \mathrm{l}$ of the DNA template. Amplification was performed in a Gene Amp $^{\text {TM }}$ PCR System 9600 (Perkin Elmer, Norwalk, CT, USA) with the following protocol: incubation at $95^{\circ} \mathrm{C}$ for $5 \mathrm{~min}$ and thereafter 40 cycles of $95^{\circ} \mathrm{C}$ for $1 \mathrm{~min}$ (denaturation); $55^{\circ} \mathrm{C}$ for $1 \mathrm{~min}$ (annealing); followed by $72^{\circ} \mathrm{C}$ for $2 \mathrm{~min}$ (extension). The amplicons were kept at $-20^{\circ} \mathrm{C}$ until further analysis. The amplified DNA fragments were separated by electrophoresis through an agarose $1.5 \%$ gel containing ethidium bromide and visualised under UV light. The amplified products were excised and eluted from the gel with a Sephaglass BandPrep kit (Pharmacia LKB Biotechnology) and cloned by the T-cloning method with a pMOSblue T-vector kit (Amersham Life Science, USA) according to the manufacturer's instructions.

\section{Hybridisation experiments}

The oligonucleotide probes used were the universal bacterial probe RDR245\# 5'-GTACAAGGCCCGGGAACGTATTCACCG-3' 1369-1395, the gram-negative probe DLO4\# 5'-GACGTAAGGGCCATGATGACTTGACGTC-3' 1190-1217 and the gram-positive universal probe RWO3\# 5'-GACGTCAAATCATCAGCCCCTTATGTC-3' $1190-1217$ as described by Greisen et al. [19]. The probes were labelled by the digoxigenin (DIG) 3'-labelling method (Boehringer Mannheim). After electrophoresis, the gels were immersed in denaturation solution $(0.5 \mathrm{~N} \mathrm{NaOH}$, $1.5 \mathrm{M} \mathrm{NaCl}$ ) twice for $15 \mathrm{~min}$, rinsed briefly in distilled water, immersed in neutralisation buffer $(0.5 \mathrm{M}$ Tris$\mathrm{HCl}, 3 \mathrm{M} \mathrm{NaCl}$ ) twice for $15 \mathrm{~min}$ at room temperature. The DNA fragments were transferred by vacuum to a Hybond $\mathrm{N}+$ nylon membrane (Amersham, Life Science) which had been soaked in sterile distilled water. After transfer, the DNA was cross-linked to the membrane for $3 \mathrm{~min}$ under UV light at $254 \mathrm{~nm}$. The membranes were pre-hybridised with blocking reagent $1 \%, 100 \mathrm{mM}$ maleic acid, $150 \mathrm{mM} \mathrm{NaCl}$ at $68^{\circ} \mathrm{C}$ for $1 \mathrm{~h}$. The DIG-labelled probe $(10 \mathrm{pmol} / \mathrm{ml})$ was prepared in $5 \times$ sodium chloride sodium citrate (SSC), blocking reagent $1 \%$, N-lauroylsarcosine $0.1 \% \mathrm{w} / \mathrm{v}$, SDS $0.02 \% \mathrm{w} / \mathrm{v}$ and placed in hybridisation bags with the membrane, and hybridised for $3 \mathrm{~h}$ at $68^{\circ} \mathrm{C}$ with constant mixing. At the end of hybridisation, the solution was removed from the bag and the membranes were washed twice for $5 \mathrm{~min}$ in $2 \times \mathrm{SSC}$, SDS $0.1 \%$ at room temperature to remove any unbound probe. Thereafter the membranes were washed twice for $15 \mathrm{~min}$, in $0.1 \times \mathrm{SSC}$, SDS $0.1 \%$ at $68^{\circ} \mathrm{C}$.

The immobilised DNA fragments on the nylon membranes were detected with the Nucleic Acid Detection kit (Boehringer Mannheim) with nitroblue tetrazolium (NBT) and X-Phosphate (BCIP) $(50 \mathrm{mg} / \mathrm{ml}$ 5-bromo-4-chloro-3-indolyl phosphate, toluidinium salt in dimethylformamide). The membranes were washed briefly for $1 \mathrm{~min}$ in $100 \mathrm{mM}$ maleic acid, $150 \mathrm{mM} \mathrm{NaCl}$ and Tween $200.3 \% \mathrm{w} / \mathrm{v}$, and then incubated for $30 \mathrm{~min}$ in blocking reagent $1 \%, 100 \mathrm{mM}$ maleic acid, $150 \mathrm{mM}$ $\mathrm{NaCl}$. The membranes were incubated for $30 \mathrm{~min}$ with anti-digoxigenin-alkaline phosphatase conjugate (150 $\mathrm{mU} / \mathrm{ml}$ ). Unbound antibody conjugate was removed by washing twice for $15 \mathrm{~min}$ with $100 \mathrm{ml}$ of buffer. The membranes were equilibrated for $2 \mathrm{~min}$ with $100 \mathrm{mM}$ Tris- $\mathrm{HCl}, 100 \mathrm{mM} \mathrm{NaCl}, 50 \mathrm{mM} \mathrm{MgCl}_{2}, \mathrm{pH} 9.5$, and 
incubated with freshly prepared colour substrate (200 $\mu \mathrm{l} \mathrm{NBT/BCIP}$ stock solution in $100 \mathrm{mM}$ Tris$\mathrm{HCl}, 100 \mathrm{mM} \mathrm{NaCl}, 50 \mathrm{mM} \mathrm{MgCl} 2, \mathrm{pH} 9.5$ ) in a sealed plastic bag in the dark without shaking. The reaction was stopped by washing the membranes with $50 \mathrm{ml}$ of $10 \mathrm{~mm}$ Tris-HCl, $1 \mathrm{~mm}$ EDTA, $\mathrm{pH} \mathrm{8.0,} \mathrm{after} \mathrm{sufficient}$ colour development was observed in the DNA fragments.

\section{Sequence determination}

All ampicillin-resistant transformants were screened for the appropriate recombinant plasmids by the standard alkaline lysis method [20] and plasmid DNA was prepared with the Qiagen Plasmid Maxi kit (Qiagen, USA). The DNA from multiple clones was purified and concentrated through a Microcon 100 microconcentrator (Amicon, USA). The double-stranded DNA templates were sequenced in both orientations with fluorescently labelled M13 and T7 sequencing primers. Sequencing was performed with an automated $\mathrm{ALF}^{\mathrm{TM}}$ DNA sequencer (Pharmacia LKB Biotechnology) and the $\mathrm{Cy} 5^{\mathrm{TM}}$ Autoread sequencing kit (Pharmacia LKB Biotechnology). All sequences were repeated and verified on an ABI Prism 377 Automated sequencer by Genomis (USA).

\section{Sequence analysis}

The three sequences were compared and aligned to known 16S rDNA sequences in the GenBank database with DNASIS v2.1 (Hitachi Software, CA, USA) [21] and MEGA (Molecular Evolutionary Genetics Analysis) [22].

\section{Results}

A 1382-bp fragment was observed in each of the samples from frozen tissue, paraffin wax-embedded tissue biopsy specimen and monocyte co-culture with primers $8 \mathrm{~F}$ and 13R. Hybridisation of the 1382-bp fragment obtained from Bam $\mathrm{HI}$ and Pst I digestion of the recombinant clones with the universal bacterial probe (RDR245) showed signals with all three samples as well as with DNA from both gram-negative and grampositive bacteria. The gram-negative probe (DLO4) hybridised to the DNA from gram-negative organisms as well as the three samples, but not to gram-positive organisms (Fig. 1a). The universal gram-positive bacterial probe (RWO3) hybridised to gram-positive organisms only and not to the DNA from the three samples or from gram-negative organisms (Fig. 1b).
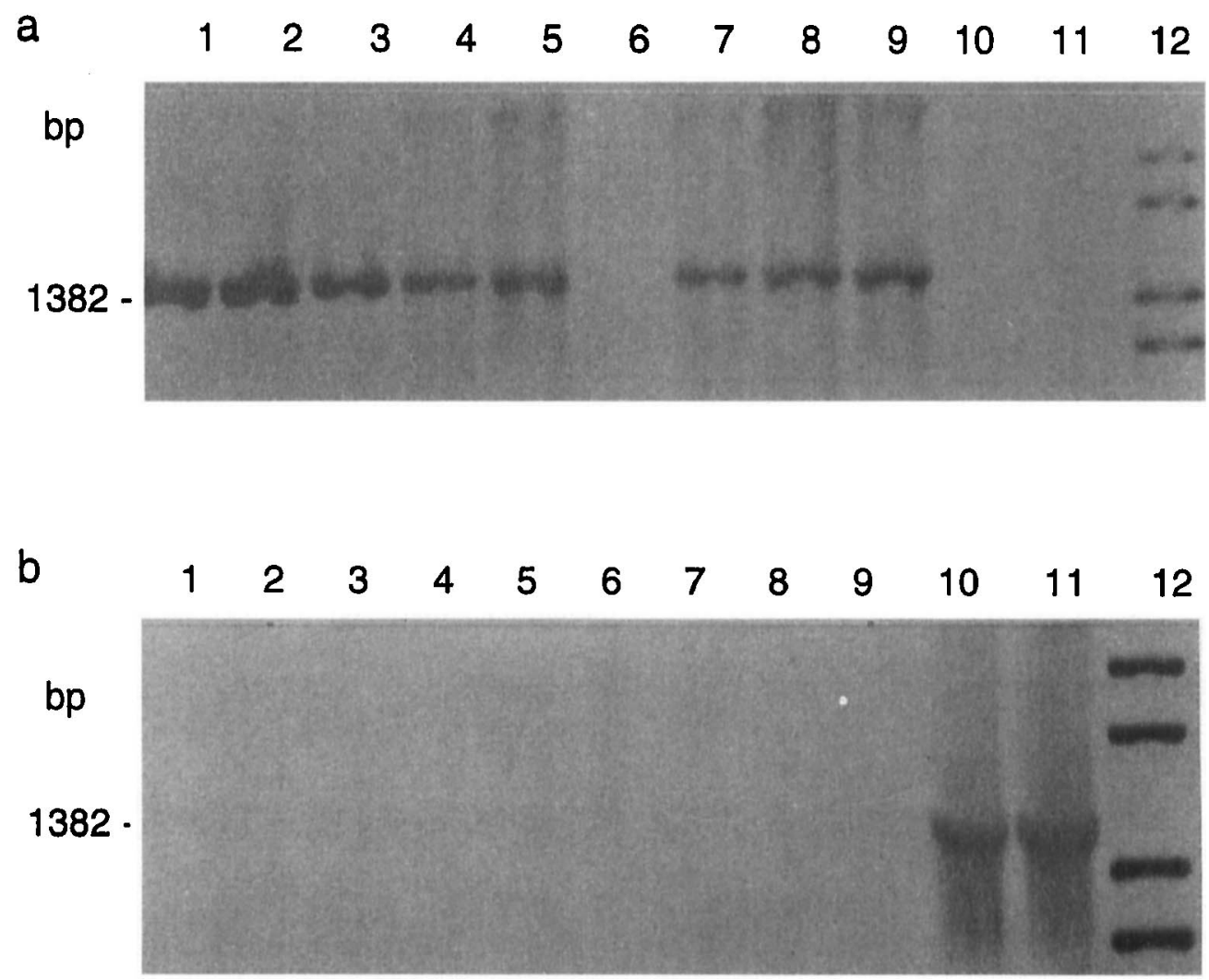

Fig. 1. Agarose 1\% gel electrophoresis of restricted recombinant clones and amplified products obtained from bacterial DNA, hybridised with (a) gram-negative bacterial probe DLO4; (b) gram-positive bacterial probe RWO3. Lane 1, frozen biopsy specimen (KH 6); 2, monocyte co-culture (KH 22); 3, formalin-fixed, paraffin wax-embedded biopsy specimen $(\mathrm{KH} 34) ; 4, E$. coli; 5, K. pneumoniae; 6, negative PCR control; 7, K. oxytoca; 8, S. marcescens; 9, A. anitratus; 10, S. aureus; 11, S. aureus; 12, DIG-labelled DNA mol.wt marker VI (pBR 328 DNA-BglI + pBR 328 DNA-Hinf1). 
Sequence analysis of 1382-bp fragments of the three samples ( $\sim 90 \%$ of the $16 \mathrm{~S}$ rRNA gene) revealed $99 \%$ homology. Single nucleotide differences observed between the sequences of the three samples were found at varying positions, as indicated in Table 1.

Alignment of the 16S rDNA sequences of $C$. granulomatis was made with sequences of the members of the Enterobacteriaceae and of representatives of several groups of bacteria of the $\alpha, \beta$ and $\gamma$ subgroups of Proteobacteria (GenBank). Similarities of $95 \%$ and 94\% were observed with $K$. pneumoniae and Enterobacter spp., whereas only $69 \%$ and $58 \%$ similarities were observed for Neisseria gonorrhoeae and Bacillus subtilis strains, respectively. The results of the comparison with other representative bacteria of the $\alpha$, $\beta$ and $\gamma$ subgroups of Proteobacteria are shown in Table 2 .

Table 1. 16S rDNA sequence differences derived from bacteria from the monocyte co-culture specimen $(\mathrm{KH}$ $22)$, frozen ( $\mathrm{KH} \mathrm{6}$ ) and formalin-fixed, paraffin waxembedded (KH 34) tissue biopsy specimen

\begin{tabular}{|c|c|c|c|}
\hline \multirow{2}{*}{$\begin{array}{l}\text { Nucleotide } \\
\text { no. }\end{array}$} & \multicolumn{3}{|c|}{ Bacterial strain } \\
\hline & $\mathrm{KH} 22$ & $\mathrm{KH} 6$ & KH 34 \\
\hline 171 & $\mathrm{C}$ & $\mathrm{T}$ & $\mathrm{T}$ \\
\hline 445 & A & $\mathrm{T}$ & $\mathrm{T}$ \\
\hline 609 & $\mathrm{C}$ & $\mathrm{T}$ & $\mathrm{T}$ \\
\hline 837 & $\mathrm{~T}$ & $\mathrm{C}$ & $\mathrm{C}$ \\
\hline 941 & $\mathrm{~T}$ & $\mathrm{G}$ & $\mathrm{T}$ \\
\hline 943 & G & $\mathrm{T}$ & $\bullet$ \\
\hline 966 & 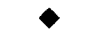 & $\mathrm{C}$ & $\mathrm{C}$ \\
\hline 968 & $\mathrm{~T}$ & $\mathrm{~T}$ & A \\
\hline 983 & $\mathrm{C}$ & $\mathrm{C}$ & $\mathrm{A}$ \\
\hline 1005 & $\mathrm{~T}$ & $T$ & $\bullet$ \\
\hline 1919 & A & A & $\bullet$ \\
\hline 1034 & A & A & $\mathrm{C}$ \\
\hline 1065 & A & A & $\diamond$ \\
\hline 1097 & $\mathrm{C}$ & $\gamma$ & $\mathrm{C}$ \\
\hline 1141 & $\mathrm{~T}$ & $\mathrm{~T}$ & $\mathrm{C}$ \\
\hline 1288 & A & $\mathrm{G}$ & $\mathrm{G}$ \\
\hline
\end{tabular}

$\checkmark$, indicates deletion.

Table 2. Levels of $16 \mathrm{~S}$ rDNA sequence similarities between $C$. granulomatis and some references species belonging to the $\alpha, \beta$ and $\gamma$ subclasses of Proteobacteria

\begin{tabular}{lc}
\hline $\begin{array}{l}\text { Bacterial species with GenBank } \\
\text { accession nos. }\end{array}$ & $\begin{array}{c}\text { Sequence similarity to } \\
\text { C. granulomatis (\%) }\end{array}$ \\
\hline Escherichia coli A14565 & 91 \\
Klebsiella pneumoniae X87276 & 95 \\
Serratia marcesens M59160 & 91 \\
Enterobacter sp. U39556 & 94 \\
Citrobacter freundii M59291 & 91 \\
Salmonella typhimurium U90316 & 91 \\
Hafnia alvei M59155 & 91 \\
Erwinia amylovora X83265 & 91 \\
Erwinia carotovora M59149 & 91 \\
Yersinia enterocolitica Z49829 & 90 \\
Yersinia aldovae X75277 & 87 \\
Acyrthosiphon pisum symbionts M27040 & 90 \\
Rhizobium leguminosarum X67233 & 60 \\
Neisseria gonorrhoeae X07714 & 69 \\
Caulobacter crescentas M83799 & 58 \\
Bacillus subtilis X60646 & 58 \\
\hline
\end{tabular}

*Values are based on the results of 1382 nucleotides.
The phylogenetic methods placed Klebsiella as the most closely related genus with strong bootstrap values. Fig. 2 shows the phylogenetic relationships among various taxa, as determined by the neighbour-joining method. All phylogenetic trees formed a cluster of the C. granulomatis sequences and this cluster was distinct from Klebsiella and other members of the Enterobacteriaceae. The relationship of this group to Klebsiella shows the evidence for the new genus Calymmatobacterium being within the taxon Enterobacteriaceae. On the basis of the phylogenetic findings, $C$. granulomatis is a member of a new genus, for which the name Calymmatobacterium is appropriate.

The sequence signatures as suggested by Woese [23] for the $\alpha, \beta$ and $\gamma$ subclasses of Proteobacteria form distinct groups. Those of the three $16 \mathrm{~S}$ rDNA sequences of $C$. granulomatis clustered within the $\gamma$ subclass. The 16S rRNA sequences determined for $C$. granulomatis have been deposited in the Genome Sequence Database (GSDP) at Los Alamos National Laboratory (formerly GenBank) under the following accession numbers: C. granulomatis monocyte coculture (strain $\mathrm{KH} \mathrm{22),} \mathrm{AF010251;} \mathrm{C.} \mathrm{granulomatis}$ frozen biopsy specimen (strain $\mathrm{KH} \mathrm{6}$ ), AF010252; $C$. granulomatis from formalin-fixed paraffin wax-embedded biopsy specimen (strain KH 34), AF010253.

\section{Discussion}

The laboratory diagnosis of granuloma inguinale is difficult. It relies only on the observation of 'Donovan bodies' in clinical specimens, which has a sensitivity of $<70 \%$ [1]. The absence of any serological identification tests and the inability to cultivate $C$. granulomatis in vitro has hampered the identification and characterisation of this organism.

In-vitro amplification technology has become a powerful tool for the rapid analysis of specific areas of DNA or even entire genes. This is the first report in which the $16 \mathrm{~S}$ rDNA of $C$. granulomatis - a previously uncultured organism implicated in the aetiology of granuloma inguinale - was amplified, cloned and sequenced from monocyte co-cultures, frozen and formalin-fixed paraffin wax-embedded tissue biopsy specimens.

Assays based on nucleic acid detection have the potential for greater sensitivity than immunological methods. In this study, oligonucleotide probes designed for the detection and identification of bacterial pathogens in normally sterile body fluids were used in the hybridisation of the restricted recombinant clones from the specimens. Hybridisation experiments performed with the specific universal bacterial (RDR245) and gram-negative (DLO4) oligonucleotide probes suggested that the restriction endonuclease-digesterd fragments from the recombinant clones from all three 


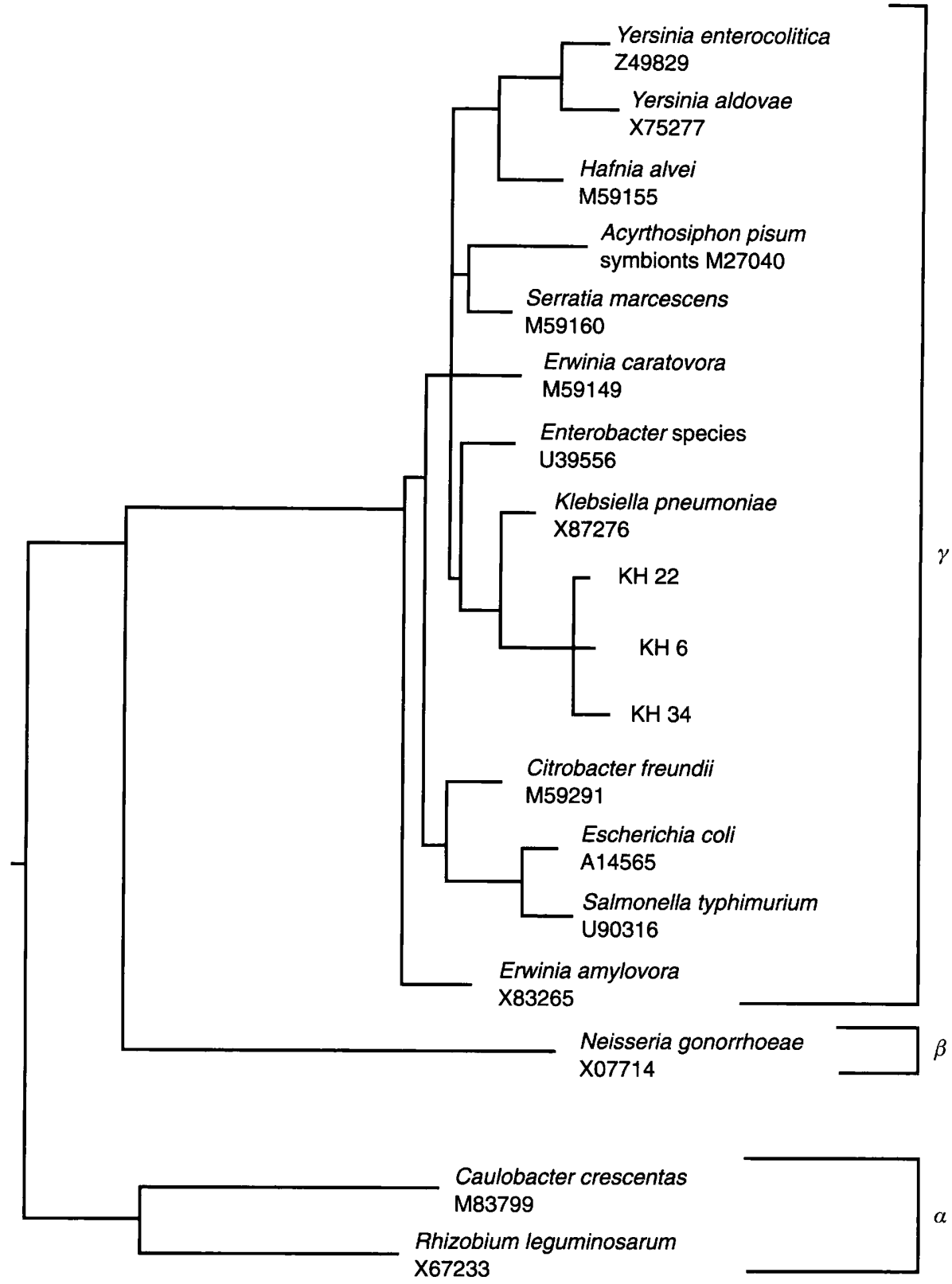

Fig. 2. Phylogenetic relationship of $C$. granulomatis $(\mathrm{KH} \mathrm{22,} \mathrm{KH} 6$ and $\mathrm{KH} 34$ ) to other bacteria of the $\alpha, \beta$ and $\gamma$ subgroups of Proteobacteria. The tree was constructed by the neighbour-joining method using MEGA. The root of the tree was determined by using the sequence of $B$. subtilis as an outgroup. The tree is based on a comparison of $1382 \mathrm{bp}$.

sources originated from eubacteria. Because no hybridisation signal was obtained with the gram-positive probe (RWO3), it was concluded that the organisms were gram-negative and not gram-positive. The grampositive probe (RWO3) corresponds to two sequence signatures identified in the 16S rRNA [19], one being a $\mathrm{C}$ residue at position 1207 and the other an $\mathrm{A}$ residue at position 1198 of the $E$. coli $16 \mathrm{~S}$ rRNA gene. The residues of the organisms at these positions were $G$ and $\mathrm{T}$ respectively. This provides further confirmation that the sequence was not from a gram-positive organism.

The comparative analyses of nucleic acid sequences coding for the 16S rRNA gene are useful for the study of phylogenetic relationships among many organisms which reflect evolutionary pathways and for characterisation of organisms of uncertain affiliation [24]. For any meaningful analysis, a part of at least $1000 \mathrm{bp}$ of the 16S rRNA gene needs to be sequenced [25]. In this study, 1382 bp of the $16 \mathrm{~S}$ rDNA ( $~ 90 \%$ of the total primary rRNA structure) were sequenced, thus permitting the sequence analysis to be undertaken with some degree of confidence.

Little is known about intra-species variations of $16 \mathrm{~S}$ rDNA sequences. Such diversity of sequences for one species may be caused by species heterogeneity, heterogeneity of the 16S rRNA copies [14] within a strain, or sequencing errors. The $16 \mathrm{~S}$ rDNA sequences of $C$. granulomatis appeared to be relatively stable, but as only a few samples were studied, no firm conclusion could be made. There are a number of possibilities for the observed sequence differences. There is evidence of very little diversity of the $16 \mathrm{~S}$ rDNA sequences of 
Francisella [26] and Legionella pneumophila [27], whereas for Borrelia burgdorferi strains, up to $1.0 \%$ divergence has been demonstrated [28]. Eckloff et al. [29] compared the 16S rDNA sequences from five isolates of Helicobacter pylori and found deviations from the consensus sequence at 13 separate positions which could be attributed to clonal origins. Relman et al. [14] reported the unique 16S rRNA gene sequences from tissues of three of four unrelated patients with bacillary angiomatosis, whilst a sequence obtained from the tissue of the fourth patient differed from that of the other three patients at four of 241 base positions. It is suggested that these sequences are all related to the 16S rRNA sequence of the same organism, but the sequence heterogeneity might indicate the presence of related strains within diseased tissue. Similarly, a small number of nucleotide differences are known to exist within the several copies of the $E$. coli rRNA gene. Another explanation for sequence difference is the fidelity of $T a q$ polymerase. Taq polymerase could misincorporate nucleotides, particularly during the amplification of damaged DNA, which would be observed after direct sequencing of PCR products. This emphasises the importance of cloning and sequence analyses of multiple clones of the amplified products from the same and different specimens in order to obtain a 'near-perfect' sequence [12]. It would be interesting to consider whether the few differences observed in the 16S rDNA sequences of $C$. granulomatis strains are reflected in phenotypic traits.

In this study, sequence analysis of the $16 \mathrm{~S}$ rDNA was able to identify bacteria from all three sources accurately as belonging to the $\gamma$ subclass of Proteobacteria, the genus being unique. Comparative sequence analysis is easy to interpret when a newly characterised sequence can be compared with a known sequence available in the database. However, at present, none of the obtained sequences could be compared with any known sequences of $C$. granulomatis from the available databases as these were unavailable. The phylogenetic tree analysis confirmed that $C$. granulomatis belonged to a separate branch of the $\gamma$ subclass of the Proteobacteria which is characterised by species belonging to the genera [23].

Although the causative agent of granuloma inguinale has been proposed to be morphologically related to Klebsiella [8], and the organisms are phylogenetically related to some extent, Klebsiella isolates were clearly distinct. Klebsiellae can be cultivated readily on cellfree media whereas calymmatobacteria are fastidious organisms and do not grow on cell-free medium. The phenotypic characteristics of klebsiellae do not resemble those of calymmatobacterium. Currently, there are no phenotypic characteristics that could easily and readily be used by clinical laboratories to differentiate calymmatobacteria from other members of the Enterobacteriaceae, particularly klebsiellae. In addition, there are no conventional or commercial tests that can identify and differentiate these organisms reliably. The use of PCR with specific primers targeting the $16 \mathrm{~S}$ rRNA gene should accurately identify and differentiate strains of $C$. granulomatis from other members of the Enterobacteriaceae. This method would provide a valuable and efficient technique which could be used by clinical microbiologists. Alternatively, the specific sequences could be used for the development of a probe for use in DNA immunoassays.

Forsman et al. [26] observed unusually high levels of sequence homology between the 16S rRNA sequences of Wolbachia persica and Francisella and suggested that instead of placing $W$. persica within the genus Francisella, the species should be further characterised phenotypically to determine its relationship to Francisella species. In a similar way, although the $16 \mathrm{~S}$ rDNA sequences of $C$. granulomatis are closely related to those of Klebsiella, they form a distinct group within the taxon Enterobacteriaceae. Thus it would be appropriate to retain the genus Calymmatobacterium. The differential phenotypic characteristics of the two groups support this proposal.

This work was supported by grants from the University of Natal research fund and the Medical Research Council of South Africa.

\section{References}

1. Richens J. The diagnosis and treatment of donovanosis (granuloma inguinale). Genitourin Med 1991; 67: 441-452.

2. Anderson $\mathrm{K}$. The cultivation from granuloma inguinale of a microorganism having the characteristics of Donovan bodies in the yolk sac of chick embryos. Science 1943; 97: 560-561.

3. Anderson K, DeMonbreun WA, Goodpasture EW. An etiologic consideration of Donovania granulomatis cultivated from granuloma inguinale (three cases) in embryonic yolk. $J$ Exp Med 1945; 81: 25-39.

4. Kharsany ABM, Hoosen AA, Kiepiela P, Naicker T, Sturm AW. Growth and cultural characteristics of Calymmatobacteriuim granulomatis: the aetiological agent of granuloma inguinale (Donovanosis). J Med Microbiol 1997; 46: 579-585.

5. Dulaney AD, Guo K, Packer H. Donovania granulomatis: cultivation, antigen preparation, and immunological tests. $J$. Immunol 1948; 59: 335-340.

6. Freinkel AL, Dangor $\mathrm{Y}$, Koornhof $\mathrm{HJ}$, Ballard RC. A serological test for granuloma inguinale. Genitourin Med 1992; 68: 269-272.

7. Kuberski T, Papadimitriou JM, Phillips P. Ultrastructure of Calymmatobacterium granulomatis in lesions of granuloma inguinale. $J$ Infect Dis 1980; 142: 744-749.

8. Rake G, Oskay JJ. Cultural characteristics of Donovania granulomatis. J Bacteriol 1948; 55: 667-675.

9. Fox GE, Stackebrant E, Hespell RB et al. The phylogeny of the prokaryotes. Science 1980; 209: 457-463.

10. Schmidt TM, Relman DA. Phylogenetic identification of uncultured pathogens using ribosomal RNA sequences. In: Clark VL, Bavoil PM (eds) Methods in enzymology: bacterial pathogenesis. Part A, Identification and regulation of virulence factors. San Diego, CA. Academic Press. 1994: 205-222.

11. Ward DM, Weller $R$, Bateson MM. 16S rRNA sequences reveal numerous uncultured microorganisms in a natural community. Nature 1990; 345: 63-65.

12. Weisburg WG, Barns SM, Pelletier DA, Lane DJ. 16S ribosomal DNA amplification for phylogenetic study. $J$. Bacteriol 1991; 173: 697-703.

13. Wilson KH. Detection of culture-resistant bacterial pathogens by amplification and sequencing of ribosomal DNA. Clin Infect Dis 1994; 18: 958-962.

14. Relman DA, Loutit JS, Schmidt TM, Falkow S, Tompkins LS 
The agent of bacillary angiomatosis. An approach to the identification of uncultured pathogens. N Engl J Med 1990; 323: $1573-1580$.

15. Relman DA, Schmidt TM, MacDermott RP, Falkow S Identification of the uncultured bacillus of Whipple's disease. $N$ Engl J Med 1992; 327: 293-301.

16. Relman DA. Universal bacterial 16S rDNA amplification and sequencing . In: Persing DH, Smith TF, Turnover FC, White TJ (eds) Diagnostic molecular microbiology: principles and applications. Washington, DC, American Society for Microbiology. 1993.

17. Wright DK, Manos MM. Sample preparation from paraffinembedded tissues. In: Innis MA, Gelfand DH, Sninsky JJ, White TJ (eds) PCR protocols: a guide to methods and applications. San Diego, Academic Press. 1990: 153-158.

18. Brosius J, Palmer ML, Kennedy PJ, Noller HF. Complete nucleotide sequence of a $16 \mathrm{~S}$ ribosomal RNA gene from Escherichia coli. Proc Natl Acad Sci USA 1978; 75: 48014805.

19. Greisen K, Loeffelholz M, Purohit A, Leong D. PCR primers and probes for the 16S rRNA gene of most species of pathogenic bacteria, including bacteria found in cerobrospinal fluid. J Clin Microbiol 1994; 32: 335-351.

20. Birnboim HC, Doly J. A rapid alkaline extraction procedure for screening recombinant plasmid DNA. Nucleic Acids Res 1979; 7: 1513-1518.

21. Higgins DG, Sharp PM. CLUSTAL: a package for performing multiple alignment on a microcomputer. Gene 1988; 73: 237-244.
22. Kumar S, Tamura K, Nei M. MEGA: molecular evolutionary genetics analysis, version 1.01. University Park, Pennsylvania, The Pennsylvania State University. 1993.

23. Woese CR. Bacterial evolution. Microbiol Rev 1987; 51: $221-$ 271.

24. Relman DA, Lepp PW, Sadler KN, Schmidt TM. Phylogenetic relationships among the agent of bacillary angiomatosis, Bartonella bacilliformis, and other alpha-proteobacteria. Mol Microbiol 1992; 6: 1801-1807.

25. Murray RGE, Brenner DJ, Colwell RR et al. Report of the ad hoc committee on approaches to taxonomy with the Proteobacteria. Int J Syst Bacteriol 1990; 40: 213-215.

26. Forsman M, Sandström G, Sjöstedt A. Analysis of $16 \mathrm{~S}$ ribosomal DNA sequences of Francisella strains and utilization for determination of the phylogeny of the genus and for identification of strains by PCR. Int J Syst Bacteriol 1994; 44: 38-46.

27. Fry NK, Warwick S, Saunders NA, Embly TM. The use of $16 \mathrm{~S}$ ribosomal RNA analyses to investigate the phylogeny of the family Legionellaceae. $J$ Gen Microbiol 1991; 137: 12151222.

28. Marconi RT, Garon CF. Phylogenetic analysis of the genus Borrelia: a comparison of North American and European isolates of Borrelia burgdorferi. $J$ Bacteriol 1992; 174: 241-244.

29. Eckloff BW, Podzorski RP, Kline BC, Cockerill FR. A comparison of $16 \mathrm{~S}$ ribosomal DNA sequences from five isolates of Helicobacter pylori. Int J Syst Bacteriol 1994; 44: $320-323$. 